\title{
Characterization of human high-density lipoprotein subclasses LP A-I and LP A-I/A-II and binding to HepG2 cells
}

\author{
Elisabeth P.C. Kilsdonk, Teus Van Gent and Arie Van Tol \\ Department of Biochemistry I, Faculty of Medicine and Health Sciences, Erasmus University Rotterdam, Rotterdam (The Netherlands)
}

(Received 9 November 1989)

(Revised manuscript received 27 March 1990)

\begin{abstract}
Key words: Apolipoprotein A-I; Apolipoprotein A-II; HDL binding; HDL subclasses; Cholesteryl ester transport;
\end{abstract} (Human hepatocyte)

\begin{abstract}
Plasma HDL can be classified according to their apolipoprotein content into at least two types of lipoprotein particles: lipoproteins containing both apo A-I and apo A-II (LP A-I / A-II) and lipoproteins with apo A-I but without apo A-II (LP A-I). LP A-I and LP A-I / A-II were isolated by immuno-affinity chromatography. LP A-I has a higher cholesterol content and less protein compared to LP A-I / A-II. The average particle mass of LP A-I is higher ( $379 \mathrm{kDa})$ than the average particle weight of LP A-I / A-II (269 kDa). The binding of ${ }^{125}$ I-LP A-I to HepG 2 cells at $4{ }^{\circ} \mathrm{C}$, as well as the uptake of $\left.\right|^{3} \mathrm{H}$ ]cholesteryl ether-labelled LP A-I by HepG2 cells at $37^{\circ} \mathrm{C}$, was significantly higher than the binding and uptake of LP A-I / A-II. It is likely that both binding and uptake are mediated by apo A-I. Our results do not provide evidence in favor of a specific role for apo A-II in the binding and uptake of HDL by HepG2 cells.
\end{abstract}

\section{Introduction}

High-density lipoproteins (HDL) play an important role in the transport of cholesterol from extrahepatic tissues to the liver, a process called reverse cholesterol transport. This role of HDL has been reinforced by studies in cultured cells, showing that HDL can accept cholesterol from cells in a process regulated by their cholesterol status [1,2]. The exact mechanism of this process is still unknown. Specific lipoprotein receptors [2-4], desorption of unesterified cholesterol from the plasma membrane followed by diffusion through the water phase [5-7] and enzyme activities like lecithin: cholesterol acyltransferase (LCAT, EC 2.3.1.43) and cholesteryl ester transfer protein (CETP) may play a role [8-10]. Although several investigators have visual-

\footnotetext{
Abbreviations: Apo A-I, apolipoprotein A-I; Apo A-II, apolipoprotein A-II; Apo E, apolipoprotein E; BSA, bovine serum albumin; CETP, cholesteryl ester transfer protein; DMEM, Dulbecco's modified Eagle's medium; ELISA, enzyme-linked immunosorbent assay; FCS, foetal calf serum; HDL, high-density lipoprotein; IAA, iodoacetic acid; kDa, kilodalton; LCAT, lecithin:cholesterol acyltransferase; LP, lipoprotein; SDS, sodium dodecyl sulphate.

Correspondence: E.P.C. Kilsdonk, Dept. Biochemistry 1, Erasmus University Rotterdam, P.O. Box 1738, 3000 DR Rotterdam, The Netherlands.
}

ized a specific binding protein for HDL [11-15], the question remains whether binding and net mass cholesterol transport are directly related [6,7]. Mendel $[16,17]$ measured a molecular mass of approx. 10 to 16 $\mathrm{kDa}$ for the functional unit of the putative HDL binding protein using radiation inactivation, while ligand blotting experiments point to a binding protein molecular mass ranging from 78 to $110 \mathrm{kDa}$ [11-15].

It has been shown that liver and steroidogenic tissues are especially active in metabolizing HDL particles. Cholesteryl esters from HDL are taken up at a greater fractional rate than apo A-I, i.e., cholesteryl esters are taken up without parallel uptake of HDL-apo A-I [18$20]$ in a process called selective uptake.

It is known that plasma HDL consists of a heterogeneous population of lipoprotein particles. The various HDL subclasses have different densities, which are used for the isolation of $\mathrm{HDL}_{2}$ and $\mathrm{HDL}_{3}$ by ultracentrifugation. Within these subfractions, particles with diameters ranging from 8 to $11 \mathrm{~nm}$ can be detected using gradient gel electrophoresis $[21,22]$. After subfractionation of HDL in seven or nine subfractions by density gradient ultracentrifugation apo A-I and apo A-II were abundant in all subfractions [23].

Chromatography on specific antibody columns is the method of choice for the isolation of HDL particles with different apolipoprotein composition $[23,24]$. HDL consists of at least two types of particles: lipoproteins 
containing both apo A-I and apo A-II (LP A-I/A-II) and lipoprotein particles with apo A-I but without apo A-II (LP A-I). In the present study we characterized the chemical compositions of LP A-I and LP A-I/A-II and measured their size by gel filtration. This is the first report on the binding and uptake of LP A-I and LP A-I/A-II by the human hepatoma cell-line HepG2.

\section{Materials and Methods}

Anti-apo A-I and anti-apo A-II immuno affinity chromatography columns, as well as the antibodics used for ELISA of apolipoproteins, were generously provided by Prof. J.C. Fruchart and Dr. P. Puchois from the Institut Pasteur in Lille (France).

Blood was collected from healthy, normolipidemic volunteers in tubes containing EDTA (final concentration $1.5 \mathrm{mg} / \mathrm{ml}$ ) and cooled on ice immediately. The subjects were starved overnight. Plasma was collected by centrifugation for $15 \mathrm{~min}$ at $1500 \times g_{\max }$ and $4^{\circ} \mathrm{C}$. All following isolation procedures were performed at $4^{\circ} \mathrm{C}$. Plasma HDL was obtained by gel filtration of 2 $\mathrm{ml}$ plasma using a Superose 6 column (prep. grade, $1.6 \times 50 \mathrm{~cm}$, Pharmacia, Uppsala, Sweden) as described in [25]. The elution buffer consisted of $0.9 \% \mathrm{NaCl}$, containing $2 \mathrm{mM}$ sodium phosphate ( $\mathrm{pH} 7.4$ ), $5 \mathrm{mM}$ EDTA and $0.02 \% \quad \mathrm{NaN}_{3}$. Plasma cholesteryl (esters), phospholipids and triacylglycerols were eluted with high recoveries [25]. The HDL fractions obtained after two runs $(2 \mathrm{ml}$ of plasma each) were pooled and applied on a combination of a Sephadex column (G25 Fine, $1.6 \times$ $35 \mathrm{~cm}$, Pharmacia, Uppsala, Sweden) directly connected with a heparin-Sepharose column $(1.3 \times 29 \mathrm{~cm})$, and eluted with $2 \mathrm{mM}$ sodiumphosphate buffer $(\mathrm{pH} 7.4)$, containing $0.1 \% \mathrm{NaN}_{3}$ [26]. No apo $\mathrm{E}$ was detectable in the HDL fraction obtained after this procedure using ELISA as described in [27].

The next isolation steps consisted of immuno-affinity column chromatography, as described by Barbaras et al. [24]. For isolation of the LP A-I/A-II particles, the apo E-free HDL fraction was passed through the immunoaffinity column with anti-apo A-II (flow $10 \mathrm{ml} / \mathrm{h}$ ). The eluate was controlled for remaining apo A-II using a highly sensitive ELISA technique [27]. The resulting apo A-II-free HDL was subsequently applied on an anti-apo A-I column, which bound all LP A-I. Both antibody columns were washed with $150 \mathrm{ml}$ of $0.9 \% \mathrm{NaCl}$ containing $0.1 \mathrm{M}$ sodiumphosphate ( $\mathrm{pH} 7.4), 0.1 \%$ EDTA and $0.1 \% \mathrm{NaN}_{3}$, followed by $30 \mathrm{ml} 0.5 \mathrm{M} \mathrm{NaCl}$ with 10 $\mathrm{mM}$ sodium phosphate ( $\mathrm{pH}$ 7.4) to elute non-specifically bound material. The HDL-subfractions were eluted with $30 \mathrm{ml} 3 \mathrm{M}$ sodiumthiocyanate, immediately followed by gel filtration on a Sephadex column (G25 Coarse, $2.6 \times 60 \mathrm{~cm}$, Pharmacia, Uppsala, Sweden). Both subfractions were concentrated by pressure dialysis using YM10 membranes (Amicon, Danvers, MA) and dialyzed against $0.9 \% \mathrm{NaCl}$ with $10 \mathrm{mM}$ sodium phosphate (pH 7.4) and $1 \mathrm{mM}$ EDTA.

Labelling of LP A-I and LP A-I/A-II with 125 or $\left[{ }^{3} H\right]$ cholesteryl linoleyl ether

The HDL-subfractions were iodinated using the ICl method (with $\mathrm{Na}^{125}$ I from Amersham International, U.K.), as described previously [28]. Labelling efficiency was 52 to $68 \%$ and the iodine/protein ratio ranged from 0.58 to 0.73 . Less than $1 \%$ of the radioactivity of the preparations was free (non-precipitable with trichloroacetic acid), 2.2-4.6\% was lipid-associated and 94 to $97 \%$ was protein-bound.

LP A-I and LP A-I/A-II were labelled with $\left[1 \alpha, 2 \alpha(\mathrm{n})-{ }^{3} \mathrm{H}\right]$ cholesteryl linoleyl ether (obtained from Amersham International, U.K.) by incubation of the subfractions with cholesteryl ether containing vesicles in the presence of CETP. The assay method and partial purification of CETP were described before [29]. LP A-I or LP A-I/A-II were incubated for $4 \mathrm{~h}$ at $37^{\circ} \mathrm{C}$ with phosphatidylcholine/cholesteryl ether vesicles (ratio of $5: 1$, formed by sonication, $\mathrm{L}-\alpha$-phosphatidylcholine P5388 from Sigma, St. Louis, MO, U.S.A.) in the presence of $0.01 \%$ EDTA and enough purified CETP to give the CETP activity level present in human plasma. $1 \mathrm{mM}$ IAA was added to inhibit LCAT. The amount of phosphatidylcholine used during the incubations was kept as low as $1 \%$ of the total HDL-phospholipids, in order to prevent changes in the phospholipid content of the particles. Lipoproteins and CETP were separated after incubation by density gradient ultracentrifugation and the HDL-subfractions were reisolated from the density range $1.063-1.21 \mathrm{~g} / \mathrm{ml}$. The specific radioactivity ranged from 50 to $80 \mathrm{dpm} / \mathrm{ng}$ protein.

After labelling, the subfractions were dialyzed against $0.9 \% \mathrm{NaCl}$ containing $10 \mathrm{mM}$ sodiumphosphate $(\mathrm{pH}$ 7.4) and $1 \mathrm{mM}$ EDTA. If necessary, the fractions were dialyzed against the cell culture medium prior to the binding experiments.

\section{Cell culture}

HepG2 cells were cultured in DMEM/F10 $0^{+}(1: 1)$ medium (DMEM was purchased from Flow Laboratories and $\mathrm{F}_{10}{ }^{+}$from Gibco), supplemented with $\mathrm{L}^{-}$ glutamine, penicilline/streptomycine and $10 \% \mathrm{FCS}$, at $37^{\circ} \mathrm{C}$ in $95 \%$ air and $5 \% \mathrm{CO}_{2}$. Cells were plated in multiwell dishes $\left(35 \mathrm{~mm}, 0.5-1.0 \cdot 10^{6}\right.$ cells $/$ well $) 3 \mathrm{~d}$ prior to each experiment. After $2 \mathrm{~d}$ the medium was removed, cells were rinsed three times with $0.9 \% \mathrm{NaCl}$ containing $10 \mathrm{mM}$ sodiumphosphate $(\mathrm{pH} \mathrm{7.4)}$ and new medium, containing either $10 \%$ FCS or $2 \%$ BSA (A-4378, Sigma, St. Louis, MO), was added to the wells. After a preincubation period of $24 \mathrm{~h}$ the cells were ready for use in the binding experiments. At that time cells were near confluency. 


\section{Lipoprotein binding studies}

After three washes with cold $0.9 \% \mathrm{NaCl}$, containing $10 \mathrm{mM}$ sodium phosphate $(\mathrm{pH} 7.4)$, the cells were placed on ice and $1 \mathrm{ml}$ test medium was added. The test medium used was culture medium (see above) in which the FCS was replaced by $2 \%$ BSA. The amount of iodinated lipoproteins in the test media ranged from 0 to $20 \mu \mathrm{g}$ protein $/ \mathrm{ml}$. Non-specific binding was measured after addition of $100 \mu \mathrm{g}$ protein $/ \mathrm{ml}$ of unlabelled LP A-I or LP A-I/A-II. This low amount of HDL-protein was used for practical reasons. Addition of high concentrations (e.g., $1 \mathrm{mg}$ protein $/ \mathrm{ml}$ ) is impractical, due to the limited capacity of the antibody columns. Therefore, we measured an apparent 'specific binding', which is somewhat lower than the real specific binding. Competition was measured using $5 \mu \mathrm{g}$ iodinated lipoprotein LP A-I or LP A-I/A-II per ml medium with $0-175 \mu \mathrm{g} / \mathrm{ml}$ unlabelled protein of the competing lipoprotein particle. For all experiments the cells were incubated for $4 \mathrm{~h}$ at $4^{\circ} \mathrm{C}$, under a $\mathrm{H}_{2} \mathrm{O}$-saturated atmosphere with $5 \% \mathrm{CO}_{2}$ and $95 \%$ air. After incubation the dishes were placed on ice, the medium was removed and the cells were washed three times with $0.2 \%$ BSA in $0.9 \% \mathrm{NaCl}$ with $50 \mathrm{mM}$ Tris- $\mathrm{HCl}(\mathrm{pH} \mathrm{7.4)}$ to remove non-specifically bound material. Then the cells were rinsed three times with $0.9 \% \mathrm{NaCl}$ containing $50 \mathrm{mM}$ Tris- $\mathrm{HCl}(\mathrm{pH} 7.4)$. The cell protein was dissolved in 2 $\mathrm{ml} 1 \mathrm{M} \mathrm{NaOH}$. The cell-bound radioactivity was measured using a gamma counter, and protein was measured according to Lowry et al. [30].

Binding plus uptake of iodinated or $\left[{ }^{3} \mathrm{H}\right]$ cholesteryl ether-labelled LP A-I and LP A-I/A-II were measured at $37^{\circ} \mathrm{C}$ at a concentration of $20 \mu \mathrm{g} / \mathrm{ml}$ of protein. This binding plus uptake will be referred to as total cell association. The overall procedure for these experiments at $37^{\circ} \mathrm{C}$ is identical with that described above for the experiments at $4^{\circ} \mathrm{C}$.

\section{Lipoprotein analyses}

The protein content of the HDI-subfractions was measured according to [30]. Total cholesterol, unesterified cholesterol, triacylglycerols and phospholipids were measured by enzymatic methods. The following kits were used: cholesterol, No. 310328 and cholesterol esterase (Boehringer Mannheim, F.R.G.); triacylglycerols, No. 877557 (Boehringer Mannheim, F.R.G.); phospholipids, No. 61491 (Bio-Mérieux, Craponne, France). Cholesteryl esters were calculated by difference of total and unesterified cholesterol.

The purity of the isolated HDL-subfractions was determined by two different methods: apolipoprotein measurements with ELISA techniques [27] and 15\% SDS-polyacrylamide gel electrophoresis [31]. Autoradiograms were made after electrophoresis of iodinated HDL-subfractions. The dried gel was exposed to Hyperfilm-MP (Amersham International, U.K.) for $3 \mathrm{~d}$ at $-80^{\circ} \mathrm{C}$.

The apo A-I and apo A-II concentrations were determined by immuno-electrophoresis [32]. The molar ratio of apo A-I to apo A-II was calculated using a $M_{\mathrm{r}}$ of $2.8 \cdot 10^{4}$ and $1.7 \cdot 10^{4}$ for apo A-I and apo A-II, respectively.

Particle weights of LP A-I and LP A-I/A-II were determined by gel filtration on a Aca 34 column (Ultrogel, Reactifs IBF, Villeneuve-la-Garenne, France). The column was calibrated with reference proteins with known molecular masses (gel filtration calibration kits No. 17-0441-01 and 17-0445-01, Pharmacia, Uppsala, Sweden). The reference proteins were: thyroglobulin $\left(M_{\mathrm{r}}=6.69 \cdot 10^{5}\right)$, ferritine $\left(M_{\mathrm{r}}=4.4 \cdot 10^{5}\right)$, catalase $\left(M_{\mathrm{r}}\right.$ $\left.=2.32 \cdot 10^{5}\right)$ and lactate dehydrogenase $\left(M_{\mathrm{r}}=1.40\right.$. $\left.10^{5}\right)$. Dextran blue $\left(M_{\mathrm{r}}=2.0 \cdot 10^{6}\right)$ was used as a marker of the void volume. The resulting $K_{\mathrm{a}}$ values were plotted against the $\log M_{\mathrm{r}}$ resulting in a regression line with a correlation coefficient of 0.999 .

For statistical analysis the non-parametric Wilcoxon test was used [33]. Results were regarded as significantly different if $P<0.05$.

\section{Results}

Table I shows that the two HDL-subfractions, LP A-I and LP A-I/A-II, differ in chemical composition. LP A-I contains less protein and more cholesterol than LP A-I/A-II. The difference in cholesterol content is caused mainly by a higher level of unesterified cholesterol in LP A-I. Consequently, LP A-I/A-II has a higher proportion of esterified cholesterol than LP A-I. The molar ratio of esterified cholesterol to unesterified cholesterol is 3.0 for LP A-I/A-II and only 1.9 for LP A-I. Not only do the chemical compositions of LP A-I and LP A-I/A-II differ, also the average particle weights are significantly different. The value for LP A-I is $379 \pm 62 \mathrm{kDa}$, (mean \pm S.D.,$n=3$ ) and the value for LP A-I /A-II is $269 \pm 17 \mathrm{kDa}$ (mean \pm S.D., $n=3$ ) (see also Fig. 1). Fig. 1 demonstrates that I.P A-I as well as LP A-I/A-II consists of particles with a wide range of

\section{TABLE I}

The chemical composition of the human HDL-subclasses $L P A-I$ and $L P$ $A-I / A-I I$

\begin{tabular}{lrc}
\hline & \multicolumn{1}{c}{ LP A-I } & LP A-I / A-II \\
\hline Protein & $55.2 \pm 3.0^{\mathrm{a}}$ & $60.3 \pm 2.4^{\mathrm{b}}$ \\
Phospholipids & $25.6 \pm 2.2$ & $23.7 \pm 2.0$ \\
Total cholesterol & $17.0 \pm 1.2$ & $13.9 \pm 0.7^{\mathrm{c}}$ \\
Unesterified cholesterol & $6.0 \pm 0.8$ & $3.5 \pm 0.1$ \\
Cholesteryl esters & $11.4 \pm 2.1$ & $10.2 \pm 0.6$ \\
Triacylglycerols & $2.9 \pm 0.4$ & $2.1 \pm 0.1$
\end{tabular}

\footnotetext{
a Values given are weight $\%($ mean \pm S.D., $n=6)$.

${ }^{b}$ Significantly different from LP A-I, $P=0.025$.

c Idem. $P=0.005$.
} 


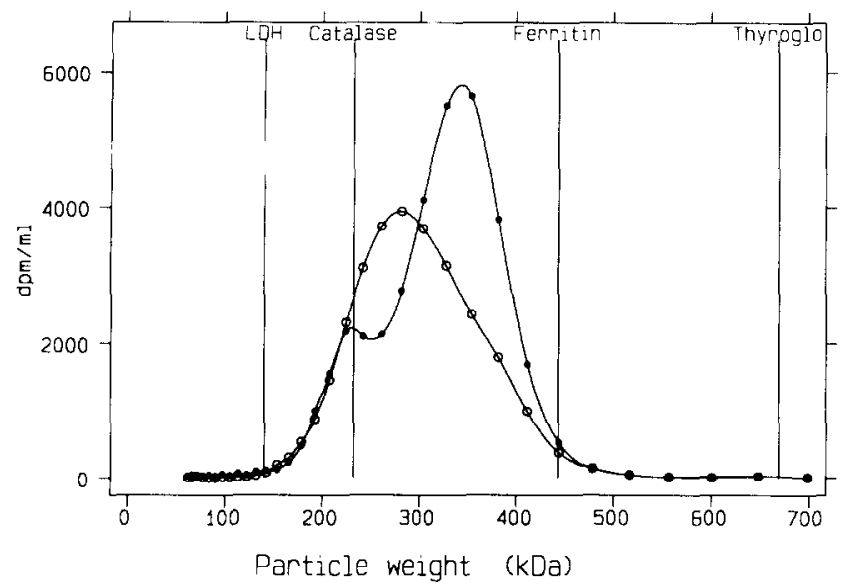

Fig. 1. A typical example of separate gel filtrations of ${ }^{3} \mathrm{H}$-cholester-

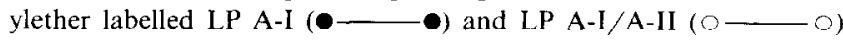
on a Aca 34 column at $4^{\circ} \mathrm{C}$. The column was calibrated with the following proteins: lactate dehydrogenase $(\mathrm{LDH})$, catalase, ferritin and thyroglobulin (Thyroglo).

diameters. The mean size of LP A-I and LP A-I/A-II varies between different individuals, but for each individual LP A-I is always bigger than LP A-I/A-II. The cholesteryl ether label and the phospholipids have similar size distributions for LP A-I as well as LP A-I/A-II (not shown). The gel filtration profile of LP A-I shows two peaks (Fig. 1): a main peak that corresponds with a

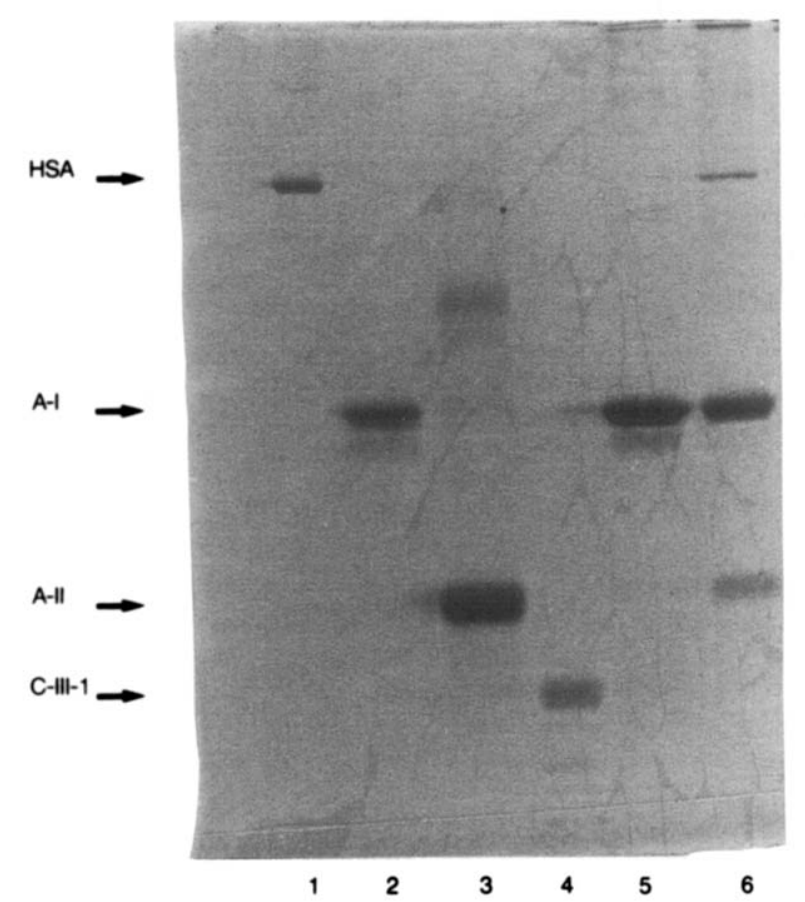

Fig. 2. Non-reduced 15\% SDS-polyacrylamide gel electrophoresis of the HDL-subfractions. Lane 1 HSA marker, lane 2 apo A-I marker, lane 3 apo A-II marker, lane 4 apo C-III-1 marker, lane 5 LP A-I and lane $6 \mathrm{LP} \mathrm{A-I/A-II}$. The gel was stained with Coomassie Brilliant Blue.

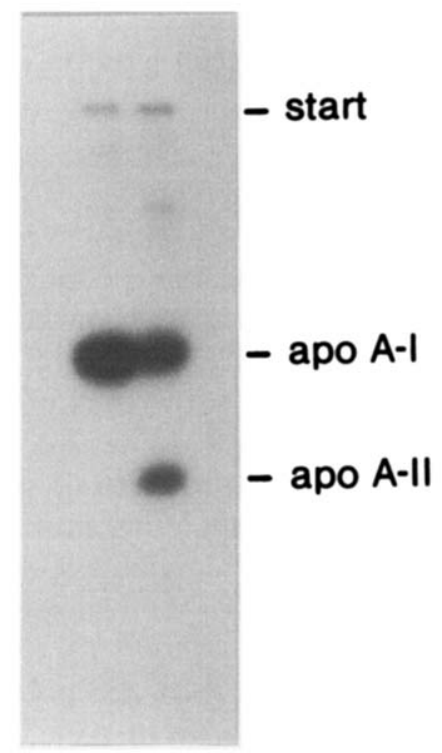

Fig. 3. Autoradiogram of ${ }^{125}$ I-LP A-I (left lane) and LP A-I/A-II (right lane) after non-reduced $15 \%$ SDS-polyacrylamide gel electrophoresis.

mean spherical particle radius of $6.2 \mathrm{~nm}$ and a smaller peak with a radius of approx. $5.2 \mathrm{~nm}$. The profile of $\mathrm{LP}$ A-I/A-II shows only one peak (Fig. 1), corresponding with a mean particle radius of $5.5 \mathrm{~nm}$.

No apo A-II could be detected in the LP A-I fraction on SDS-polyacrylamide gel electrophoresis (Fig. 2). There was only a very small amount of contaminating protein (co-migrating with HSA) visible in the LP AI/A-II fraction. A minor protein band, migrating slightly faster than the main band of apo A-I, was present in LP A-I as well as in the pure apo A-I marker. The nature of this minor band, which is not present in LP A-I/A-II, is presently unknown. It is likely to be a

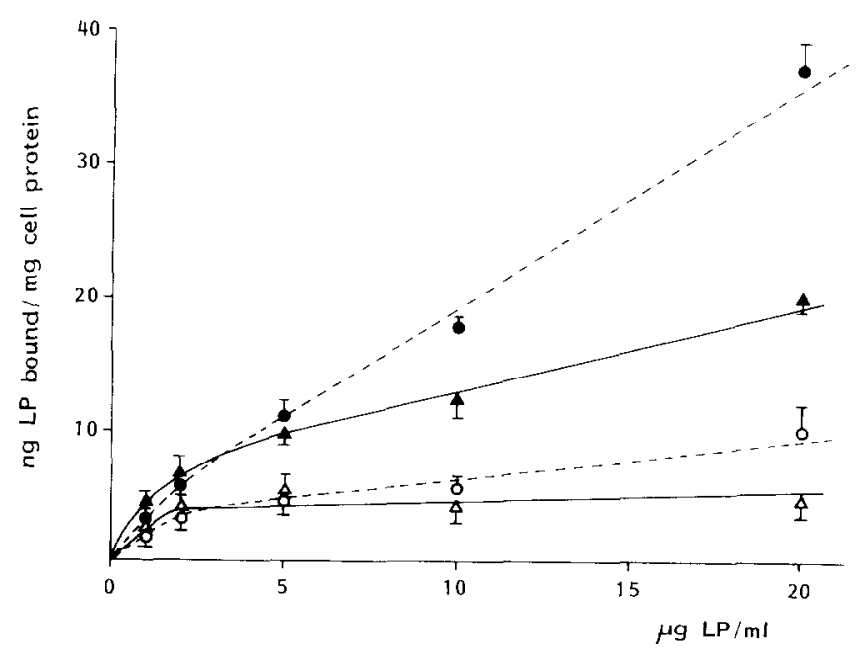

Fig. 4. The total (closed symbols) and "specific binding" (open symbols) at $4^{\circ} \mathrm{C}$ of LP A-I $(\bullet, 0)$ and LP A-I / A-II $(\bullet, \Delta)$ to HepG2 cells (ng HDL protein/mg cell protein, values are given as means \pm S.E.M., $n=3$ )) 


\section{TABLE II}

Competition of the binding of iodinated $L P A-I$ and iodinated $L P$ $A-I / A-I I$ by unlabelled LP A-I/A-II or LP A-I in HepG2 cells at $4^{\circ} \mathrm{C}$

\begin{tabular}{llccc}
\hline $\begin{array}{l}\text { Ligand } \\
(5 \mu \mathrm{g} / \mathrm{ml})\end{array}$ & Competitor & $\begin{array}{l}\text { Competitor } \\
(\mu \mathrm{g} / \mathrm{ml})\end{array}$ & \multicolumn{2}{c}{$\begin{array}{l}\text { \% Labelled } \\
\text { ligand bound }\end{array}$} \\
\hline${ }^{125} \mathrm{I}-\mathrm{LP}$ A-I & LP A-I/A-II & 0 & $100^{2}$ & $(n=3)$ \\
& 35 & $92 \pm 16^{\mathrm{b}}$ & $(n=3)$ \\
& 75 & $65 \pm 1$ & $(n=2)$ \\
& 135 & $60 \pm 4$ & $(n=2)$ \\
& & $59 \pm 1$ & $(n=2)$ \\
& & & & \\
${ }^{125}$ I-LP A-I/ & & 0 & 100 & $(n=3)$ \\
A-II & LP A-I & 35 & $62 \pm 6^{\mathrm{b}}$ & $(n=3)$ \\
& & 75 & $51 \pm 1$ & $(n=2)$ \\
& & 135 & $49 \pm 5$ & $(n=2)$ \\
& & 175 & $43 \pm 1$ & $(n=2)$ \\
\hline
\end{tabular}

a Values are means ( \pm S.E.M.).

bignificant difference between the $\%$ found for LP A-I and LP A-I $/$ A-II competition (Wilcoxon's non-parametric test, $P<0.05$ ).

degradation product of apo A-I. Evidence in favor of a high sensitivity for proteolytic degradation in specific HDL subfractions has been published recently [34]. ELISA assays showed that the percentage of apo A-II in the LP A-I subfraction is less than $0.1 \%$, apo C-III (quantitatively the most important apo $\mathrm{C}$ in $\mathrm{HDL}$ ) ranged from $1-3 \%$, and apo $E$ was less than $0.5 \%$ of total apolipoprotein. The molar ratio of apo A-I/apo A-II in the LP A-I/A-II subfraction, measured in delipidated samples, was $1.4 \pm 0.2$ (mean \pm S.E.M., $n=5$ ).

Fig. 3 shows an autoradiogram obtained after SDSpolyacrylamide gel electrophoresis of iodinated LP A-I and LP A-I/A-II. Only very little radioactivity is present in proteins other than apo A-I or apo A-II.

Fig. 4 shows the binding of iodinated LP A-I and LP A-l/A-Il to HepG2 cells, measured at $4^{\circ} \mathrm{C}$. The total binding of LP A-I was high compared to the binding of LP A-I/A-II. Both HDL-subfractions showed a saturable 'specific binding' of about $50 \%$ of the total binding, if measured at a lipoprotein concentration of $5 \mu \mathrm{g} / \mathrm{ml}$.

\section{TABLE III}

The binding and uptake of the protein and cholesteryl ester moieties of $L P A-I$ and LP A-I/A-II by HepG 2 cells at $37^{\circ} \mathrm{C}$

\begin{tabular}{llll}
\hline & \multicolumn{1}{c}{ I-protein } & ${ }^{3} \mathrm{H}$-lipid & Ratio ${ }^{3} \mathrm{H}:{ }^{125} \mathrm{I}$ \\
\hline Preincubation of cells in $10 \%$ FCS: & & \\
LP A-I & $0.36 \pm 0.02^{\mathrm{a}}$ & $1.24 \pm 0.05^{\mathrm{a}}$ & 3.4 \\
LP A-I/A-II & $0.29 \pm 0.02^{\mathrm{b}}$ & $0.74 \pm 0.06^{\mathrm{b}}$ & 2.5 \\
Preincubation of cells in 2\% BSA: & \\
LP A-I & $0.34 \pm 0.01$ & $0.77 \pm 0.01$ & 2.3 \\
LP A-I A-II & $0.29 \pm 0.01^{\mathrm{b}}$ & $0.54 \pm 0.03^{\mathrm{b}}$ & 1.9
\end{tabular}

\footnotetext{
a All values are cell-associated radioactivity expressed in $\%$ of added radioactivity, mean \pm S.E.M., $n=3$ ).

${ }^{b}$ Significantly different from the value for LP A-I, $P<0.05$.
}

The construction of accurate Scatchard plots for the calculation of binding affinities and maximal binding was not possible, due to the limited number of measurements. Table II shows the competition of LP A-I/A-II for ${ }^{125}$ I-LP A-I binding and of LP A-I for ${ }^{125}$ I-LP A-I/A-II binding. Both subfractions are able to displace each other, although LP A-I can displace more ${ }^{125}$ I-LP A-I/A-II, especially at low concentrations. Table III gives the data on total HDL association to HepG2 cells at $37^{\circ} \mathrm{C}$. The cells were incubated with 20 $\mu \mathrm{g}$ HDL protein/ml, using different preincubation conditions. Two differently labelled preparations were used: ${ }^{125} \mathrm{I}$-apolipoprotein label and $\left[{ }^{3} \mathrm{H}\right]$ cholesteryl ether label. The results show that the binding of LP A-I is significantly higher than that of LP A-I/A-II. This finding is not dependent on the preincubation conditions. The cholesteryl ether-derived cell-associated radioactivity was higher than that derived from iodinated lipoproteins (expressed as \% of the added radioactivity), indicating a preferential uptake of cholesteryl ether over apolipoproteins. This selective uptake occured for both L.P A-I and LP A-I/A-II. The ratio cholesteryl ether uptake/apolipoprotein uptake ranged from 1.9 to 3.4 .

\section{Discussion}

The differences between LP A-I and LP A-I/A-II resemble the known differences between $\mathrm{HDL}_{2}$ and $\mathrm{HDL}_{3}$. Both LP A-I and HDL 2 have a relatively low protein content and a relatively high total cholesterol content. The esterification level is highest in LP A-I/AII and $\mathrm{HDL}_{3}$. The observed protein contents of both LP A-I and LP A-I/A-II (55 and 60\%, respectively) are higher than those reported for HDL isolated by ultracentrifugation [35]. $\mathrm{HDL}_{2}$ and $\mathrm{HDL}_{3}$ contain about $40 \%$ and $53 \%$ protein, respectively. The most likely explanation for these differences in protein content hetween the two isolation methods is 'stripping' of HDL-apolipoproteins during ultracentrifugation [36,37]. Kunitake et al. [36] showed that $20 \%$ of the total apo A-I of human HDL was lost after one $24 \mathrm{~h}$ ultracentrifugation at high salt concentration. Cheung and Wolf [37] found that $14 \%$ of the apo A-I of LP A-I was found in the $d>1.21 \mathrm{~g} / \mathrm{ml}$ fraction after ultracentrifugation. About $9 \%$ of rat HDL apo A-I is lost during one ultracentrifugal step $[38,39]$.

The high protein content of LP A-I and LP A-I / A-II is a common finding after isolation of HDL-subfractions by immuno-affinity column chromatography. McVicar et al. [40] isolated apo A-I containing particles with 62-70\% protein. Cheung and Wolf [37] isolated LP A-I particles with 43-56\% and LP A-I/A-II particles with $55-60 \%$ protein. Lower values (34-46\% of protein) were calculated by summation of the specific apolipoprotein concentrations [41]. However, absolute standardization of these apolipoprotein assays is difficult 
and total protein determination will probably result in more reliable data.

The isolated HDL-subfractions had average particle masses of about 380 and $270 \mathrm{kDa}$ for LP A-I and LP A-I/A-II, respectively. The particle mass for LP AI/A-II measured by us was higher than the values reported for $\mathrm{HDL}_{3}[42,43]$. This again may be caused by the avoidance of ultracentrifugation (see above). Changes in apo A-I containing particles due to ultracentrifugation were described before $[40,44]$. Vezina et al. [44] showed that apo A-I containing lipoproteins may have particle mass up to $815 \mathrm{kDa}$, if separated by gradient gel electrophoresis. After prior ultracentrifugation, no apo A-I containing lipoproteins with average particle masses above $390 \mathrm{kDa}$ could be detected anymore. In another study [40], apo A-I containing particles, isolated by immuno-affinity chromatography, also had higher mean particle radii than HDL isolated by ultracentrifugation.

The subdivision of LP A-I in two subfractions (see Fig. 1) is also evident on gradient gel electrophoresis $[45,46]$. In [45] the main band consisted of lipoproteins of approx. $300 \mathrm{kDa}$ and the smaller band was about 164 $\mathrm{kDa}$. The LP A-I isolated in our study was bigger: the major component has a particle weight of approx. 380 $\mathrm{kDa}$. The mean particle size of LP A-I and LP A-I/A-II reported in part of the existing literature is somewhat smaller than the values obtained in the present study. This may be partly due to the method of analysis: measurements by gel filtration give slightly higher values for the radii of HDL particles, compared to gradient gel electrophoresis [47]. From our data we calculated mean particle radii of $6.2 \mathrm{~nm}$ for LP A-I and of $5.5 \mathrm{~nm}$ for LP A-I/A-II. Using the same method, i.e., gel filtration, Cheung et al. [47] found similar results for LP A-I $(5.7$ to $6.5 \mathrm{~nm})$ and higher values for LP A-I $/$ A-II $(6.0$ to $6.3 \mathrm{~nm})$. Size measurements using the electron microscope showed apo A-I containing par-

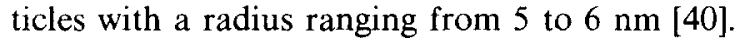

We find a molar ratio of apo A-I/apo A-II in LP A-I/A-II particles of $1.4 \pm 0.2$. From a study of Ohta et al. [41] a ratio of 1.5 for women and 1.6 for men can be calculated. James et al. [48] measured a ratio of $1.5 \pm 0.1$. Cheung and Albers [45] isolated particles with a ratio of 2 and showed that ultracentrifugation had no effect on the apo A-I/apo A-II molar ratio. However, the major fraction of the LP A-I/A-II particles they isolate contains 2 molecules of apo A-I and 1-2 molecules of apo A-II [49]. In our study at least 3 molecules of apo A-I and 2 molecules of apo A-II appear to be present on each LP A-I/A-II particle. For LP A-I, 2-4 apo A-I molecules per particle were proposed before [50,51]. From the data obtained in this study we calculate that the average LP A-I particle may contain 7-8 molecules of apo A-I. This high number follows from the combination of a relatively high protein content as well as particle weight of the LP A-I subfraction. Separate gel filtration of the two subfractions (Fig. 1) showed that both subfractions consisted of particles with greatly variable size. This is not caused by an overloading of the column. Comparable amounts of protein of the calibration standards gave narrow peaks. This implies that affinity chromatography is necessary to isolate pure LP A-I and LP A-I/A-II, and that gel filtration alone or ultracentrifugation alone cannot provide pure subfractions.

In all our experiments the binding and uptake of LP A-I was higher compared to LP A-I/A-II. For both subfractions the specific binding was about $50 \%$ of the total amount of bound HDL. Other investigators also measured a relatively high non-specific binding of HDL to HepG2 cells [52]. When the binding of LP A-I/A-II is related to the concentration of apo A-I the binding curves of LP A-I and LP A-I/A-II do not differ anymore (not shown), suggesting that only apo A-I mediates the binding. The fact that LP A-I was able to displace bound ${ }^{125}$ I-LP A-I/A-II also supports the role of apo A-I in the binding of HDL to its binding site. These competition experiments are not interfered with by exchange of labelled apo A-I (on bound iodinated lipoprotein) with unlabelled competing apo A-I. This type of exchange could cause apparent competition [53]. Exchange of apolipoproteins between different particles does not occur at $4^{\circ} \mathrm{C}$ however [54].

Whether both apo A-I and apo A-II are ligands for the binding of HDL remains controversial. There are only two other studies in which LP A-I and LP A-I/A-II particles were used in binding experiments. Pig liver, adrenal and skeletal muscle membranes [55] also show a higher binding of LP A-I compared to LP A-I/A-II. Differentiated Ob1771 mouse adipocytes show binding of apo A-I, as well as apo A-II-containing liposomes [56]. In this study, a striking difference in the function of the two HDL-subfractions was found when cholesterol efflux from adipocytes was measured [24,56,57]. Apo A-II-containing liposomes and LP AI/A-II failed to promote cholesterol efflux, resulting in the hypothesis that apo A-II has an antagonistic effect on cholesterol efflux. Another study shows that apo A-II on HDL inhibits HDL-binding to adipocyte cell membranes [58]. $\mathrm{HDL}_{3}$-binding to human adipocyte membranes decreased $92 \%$ after enrichment of $\mathrm{HDL}_{3}$ with apo A-II. In our study with HepG2 cells LP A-I and LP A-I/A-II were both bound to about the same extent and cholesterylether uptake from HDL was comparable. In several studies using ligand blotting, apo A-I as well as apo A-II are able to bind to a receptor protein in membranes of various cell types, e.g., liver, adrenal cortex, kidney, fibroblasts, smooth muscle cells, macrophages and adipocytes $[13,57,59]$. In contrast, Schmitz et al. [60] state that only apo A-I is the ligand for the HDL receptor, since only anti-apo A-I was able 
to inhibit binding of HDL to peritoneal macrophages. Anti-apo A-II, anti-apo E and anti-apo C's did not inhibit HDL-binding.

A selective uptake of HDL-cholesteryl ether, compared to HDL-apolipoprotein, was observed in HepG2 cells, measured at $37^{\circ} \mathrm{C}$, confirming earlier reports $[19,61]$. In our experiments $\left[{ }^{3} \mathrm{H}\right]$ cholesteryl ether was used as a non-degradable label. Theoretically the ${ }^{125} \mathrm{I}$ label will be released from the cells after degradation of the apolipoproteins. However, no degradation could be measured during the short incubation periods used in our experiments (not shown). The selective uptake was higher for LP A-I than it was for LP A-I/A-II, but the differences were small. Our results do not support a specific role for apo A-II in the uptake of HDLcholesteryl esters.

The effects of CETP, secreted by HepG2 cells [62], could influence our results. However, no CETP activity is detectable in the medium after $4 \mathrm{~h}$ of incubation (not shown). Recently, Rinninger and Pittman [19] showed that secreted CETP activity does not influence HDLcholesteryl ether uptake during short incubation periods.

This study describes for the first time the binding and uptake of HDL-subfractions, isolated by immunoaffinity chromatography, to HepG2 cells. No big differences in the binding or uptake of LP A-I and LP A-I/A-II were observed and no specific role of apo A-II in HDL-binding or uptake of cholesteryl esters was detected.

\section{Acknowledgements}

Profs. P. Puchois and J.-C. Fruchart from the Institut Pasteur (Lille, France) are thanked for their help in the ELISA for apolipoproteins and for generously providing the antibody columns. We also thank Dr. J.E.M. Groener for the isolation of purified CETP and for the measurements of CETP activity. The investigations were supported (in part) by the Netherlands Foundation for Chemical Research (SON) with financial aid from the Netherlands Organisation for the Advancement of pure Research (NWO).

\section{References}

1 Oram, J.F., Albers, J.J., Cheung, M.C. and Bierman, E.L. (1981) J. Biol. Chem. 256, 8348-8356.

2 Oram, J.F. (1983) J. Clin. Invest. 72, 1611-1621.

3 Rifici, V.A. and Eder, H.A. (1984) J. Biol. Chem. 259, 1381413818.

4 Schmitz, G., Robenek, H., Lohman, U. and Assman, G. (1985) EMBO J. 4, 613-622.

5 Johnson, W.F., Bamberger, M.J., Latta, R.A., Rapp, P.E., Phillips, M.C. and Rothblat, G.H. (1986) J. Biol. Chem. 261, 5766-5776.

6 Karlin, J.B., Johnson, W.J., Benedict, C.R., Chacko, G.K., Phillips, M.C. and Rothblat, G.H. (1987) J. Biol. Chem. 262, 12557-12565.
7 Johnson, W.J., Mahlberg, F.H., Chacko, G.K., Phillips, M.C. and Rothblat, G.II. (1988) J. Biol. Chem. 263, 14099-14106.

8 Granot, E., Tabas, I. and Tall, A.R. (1987) J. Biol. Chem. 262 , 3482-3487.

9 Morton, R.E. (1988) J. Lipid Res. 29, 1367-1377.

10 Rinninger, F. and Pittman, R.C. (1989) J. Biol. Chem. 264, 6111 6118 .

11 Fidge, N., Kagami, A. and O'Connor, M. (1985) Biochem. Biophys. Res. Commun. 129.759-765.

12 Fidge, N.H. (1986) FEBS Lett. 199. 265-268.

13 Graham, D.L. and Oram, J.F. (1987) J. Biol. Chem. 262. 74397442.

14 Monaco, L.. Bond, H.M., Howell. K.E. and Cortese. R. (1987) EMBO J. 6, 3253-3260.

15 Eder, H.A., Mitchel, Y.B., Arbeeny, C.M. and Rifici, V.A. (1989) in High-Density Lipoproteins and Atherosclerosis, II (Miller, N.E. ed.), pp. 159-171, Elsevier, Amsterdam.

16 Mendel, C.M., Kunitake, S.T., Kane, J.P. and Kempner, E.S. (1988) J. Biol. Chcm. 263, 1314-1319.

17 Mendel, C.M., Kunitake, S.T.. Hong, K.. Erickson, S.K.. Kane, J.P. and Kempner. E.S. (1988) Biochim. Biophys. Acta 961, 188193.

18 Pittman, R.C. and Steinberg, D. (1986) in Receptor-Mediated Uptake in the Liver (Greten H., Windler E. and Beisiegel, U, eds.), pp. 108-119, Springer-Verlag, Berlin-Heidelberg.

19 Pittman, R.C.. Knecht, T.P.. Rosenbaum, M.S. and Taylor. C.C. Jr. (1987) J. Biol. Chem. 262, 2443-2450.

20 Rinninger, F. and Pittman, R.C. (1987) J. Lipid Res. 28, 1313 1325.

21 Blanche, P.J., Gong, E.L., Forte, T.M. and Nichols, A.V. (1981) Biochim. Biophys. Acta 665, 408-419.

22 Clifton, P.M., MacKinnon, A.M. and Barter, P.J. (1987) J. Chromatogr. 414, 25-34.

23 Cheung, M.C. and Albers, J.J. (1982) J. Lipid Res. 23, 747-753.

24 Barbaras, R., Puchois, P., Fruchart, J.C. and Ailhaud, G. (1987) Biochem. Biophys. Res. Commun. 142, 63-69.

25 Van Gent, T. and Van Tol, A. (1990) J. Chromatogr. 525, 433-441.

26 Quarfordt, S.H., Jain, R.S., Jakoi, L., Robinson, S. and Shelburne, F. (1978) Biochem. Biophys. Res. Commun. 83, 786-793.

27 Fruchart, J.C.. Fievet, C. and Puchois, P. (1985) in Methods of Enzymatic Analysis (Bergmeyer, H.U., ed.). Vol. 8, pp. 126-138, $\mathrm{VCH}$ Verlagsgesellschaft, Weinheim.

28 Van Tol, A., Van Gent, T., Van 't Hooft, F.M. and Vlaspolder, F. (1978) Atherosclerosis 29, 439-448.

29 Groener, J.E.M. and Kostner, G.M. (1987) J. Lipid Res. 28 , $1053-1056$

30 Lowry, O.H., Rosebrough, N.J., Farr, A.L. and Randall, R.T. (1951) I. Biol. Chem. 193, 265-275

31 Laemmli, U.K. (1970) Nature 227. 680-685.

32 Laurell, C.B. (1966) Anal. Biochem. 15, 45-52.

33 Armitage, P. and Berry, G. $\left(1987^{2}\right)$ Statistical Methods in Medical Research, pp. 411-417, Blackwell, Oxford

34 Kunitake, S.T., Chi Chen, G., Kung, S.-F., Schilling. J.W., Hardman, D.A. and Kane, J.P. (1990) Arteriosclerosis 10, 25-30.

35 Groot, P.H.E., Scheek, L.M., Havekes, L., Van Noort, W.L. and Van 't Hooft, F.M. (1982) J. Lipid Res. 23, 1342-1353.

36 Kunitake, S.T. and Kane, J.P. (1982) J. Lipid Res. 23, 936-940.

37 Cheung, M.C. and Wolf, A.C. (1988) J. Lipid Res. 29, 15-25

38 Fainaru, M., Havel, R.J. and Imaizumi. K. (1977) Biochem. Med. $17,347-355$.

39 Dallinga-Thie, G.M., Groot. P.H.E. and Van Tol, A. (1985) J. Lipid Res. 26, 970-976

40 McVicar, J.P., Kunitake, S.T.. Hamilton, R.L. and Kane, J.P. (1984) Proc. Natl. Acad. Sci. USA 81, 1356-1360.

41 Ohta, T., Hattori, S.. Nishiyama, S. and Matsuda, I. (1988) J. Lipid Res. 29, $721-728$. 
42 Levy, R.I., Blum, C.B. and Schaefer, E.J. (1976) in Lipoprotein Metabolism (Greten, H. ed.), pp. 56-64, Springer-Verlag, New York.

43 Eisenberg, S. (1984) J. Lipid Res. 25, 1017-1058.

44 Vézina, C.A., Milne, R.W., Weech, P.K. and Marcel, Y.L. (1988) J. Lipid Res. 29, 573-585.

45 Cheung, M.C. and Albers, J.J. (1984) J. Biol. Chem. 259, $12201-$ 12209.

46 Nichols, A.V., Gong, E.L., Blanche, P.J. and Forte, T.M. (1989) in High-Density Lipoproteins and Atherosclerosis, II (Miller, N.E. ed.), pp. 159-171, Elsevier, Amsterdam.

47 Cheung, M.C., Wolf, A.C., Lum, K.D., Tollefson, J.H. and Albers, J.J. (1986) J. Lipid Res. 27, 1135-1144.

48 James, R.W., Hochstrasser, D., Tissot, J.-D., Funk, M., Appel, R., Barja, F., Pellegrini, C., Muller, A.F. and Pometta, D. (1988) J. Lipid Res. 29, 1557-1571.

49 Albers, J.J. and Cheung, M.C. (1989) in High-Density Lipoproteins and Atherosclerosis, II (Miller, N.E. ed.), pp. 173-179, Elsevier Amsterdam.

50 Nichols, A.V., Cheung, M., Blanche, P., Gong, E. and Albers, J. (1985) Circulation 72, III-364.

51 Cheung, M.C., Segrest, J.P., Albers, J.J., Cone, J.T., Brouillette, C.G., Chung, B.H., Kashyap, M.K., Glasscock, M.A. and Anantharamaiah, G.M. (1987) J. Lipid Res. 28, 913-929.
52 Dashti, N., Wolfbauer, G. and Alaupovic, P. (1985) Biochim. Biophys. Acta 833, 100110.

53 Havekes, L., Schouten, D., Van Hinsbergh, V. and De Wit, E. (1984) Biochem. Biophys. Res. Commun. 122, 785-790.

54 Van Tol, A., Dallinga-Thie, G.M., Van Gent, T. and Van 't Hooft, F.M. (1986) Biochim. Biophys. Acta 876, 340-351.

55 De Crom, M.P.G., Van IIaperen, M.J., Puchois, P., Fruchart, J.C., Van Gent, T., Van Tol, A. and Van Der Kamp, A.W.M. (1989) Int. J. Biochem. 21, 649-656.

56 Barbaras, R., Grimaldi, P., Negrel, R. and Ailhaud, G. (1986) Biochim. Biophys. Acta 888, 143-156.

57 Barbaras, R., Puchois, P., Grimaldi, P., Barkia, A., Fruchart, J.C. and Ailhaud, G. (1987) Biochem. Biophys. Res. Commun. 149, $545-554$.

58 Fong, B.S., Salter, A.M., Jimenez, J. and Angel, A. (1987) Biochim. Biophys. Acta 920, 105-11357.

59 Fidge, N.H. and Nestel, P.J. (1985) J. Biol. Chem. 260, 3570-3575.

60 Schmitz, G., Niemann, R., Brennhausen, B., Krause, R. and Assman, G. (1985) EMBO J. 4, 2773-2779.

61 Rinninger, F. and Pittman, R. (1988) J. Lipid Res. 29, 1179-1194.

62 Swenson, T.L., Simmons, J.S., Hesler, C.B., Bisgaier, C. and Tall, A.R. (1987) J. Biol. Chem. 262, 16271-16274. 